\title{
A DESCRIPTIVE STUDY UPON THE CULTURE SPECIFIC ITEMS WITHIN THE PERSPECTIVE OF NEWMARK'S TRANSLATION PROCEDURES ${ }^{1}$
}

\author{
Adem AKALIN ${ }^{2}$
}

\begin{abstract}
It is a general fact that translation plays a fundamental role in the interaction and communication of different nations, languages and cultures. Many words and phrases have been translated because of the fact that humankind needed to communicate among themselves within the variety of languages and cultures on earth throughout the history. As literature stands for one of the components constituting the language and culture, it spreads over the world and may get into connection with a lot of foreign languages. For this reason, a translation of an art of work bears high importance in terms of its being understood by the target reader completely and its transference to the target language without any loss from its essence. In this study, two translations of ' 72 . Koğuş' by Orhan Kemal will be studied in terms of the transferring the culture specific items into English as the target language. The main purpose of the study is to examine the translation methods and strategies that were utilized during the process of translating the culture specific items in the novella, '72. Koğuş' by Orhan Kemal, within the framework of Newmark's translation procedures. As a result of this study, approximately 500culture specific items that were used by the author of source text were detected via Newmark's Taxonomy of Culture Specific Items and examined in their translations into English in terms of the translation procedures and strategies that were used by the translators. 33 culture specific items were selected randomly to be examined in the study.
\end{abstract}

Key Words: Culture Specific Items, Translation Procedures, Peter Newmark, Orhan Kemal, 72. Koğuş.

\section{INTRODUCTION}

There have been many different civilizations and cultures on earth since the beginning of humankind. In order to get into an interaction in terms of being informed about other cultures and nations, something in common was needed by these civilizations. The interaction among these civilizations has been supplied by the help of translation. As a means of communication, translation has the role of being a bridge between different nations, cultures and civilizations, by this way humankind has been in touch with his environment permanently.

Even though translation has an old history and has been utilized by humankind through centuries, no significance has been given to it as a field and its independence as a discipline was declared under the name of 'translation studies' in the late of $20^{\text {th }}$ century by James Holmes, a Dutch-based American scholar. Thanks to his paper named as 'The name and the Nature of Translation', translationgained its unique and independent form and accepted as a phenomenon separated from other disciplines, but bound to other scientific fields in some way. (Holmes, 1972) It was an initial step to declare the translation as independent discipline apart from the others. However, translation is bound up to them in some way. Since it deals with a great diversity of languages, cultures, traditions, societies and shortly everything that constitutes

\footnotetext{
${ }^{1}$ Prepared as a part of my PhD dissertation at the department of Translation and Interpreting at Gazi University, Ankara / Turkey

${ }^{2}$ Öğr. Gör. Dr. Ağrı İbrahim Çeçen Üniversitesi, Yabancı Diller Yüksek Okulu, Çeviribilim / MütercimTercümanlık Bölümü, e-posta: ademakalin86@gmail.com
} 
language and its components, an interaction with the disciplines that are related with language is inevitable for translation. For that reason, translation became an inter-disciplinary field that has relationship with the other sciences. After gaining the independence, the field of 'translation studies' has made progress considerably since 1970s. The act of translating started to be handled with culture since it was realized that culture is an inseparable part of the process of translating.

The definition of translation has been made by many scholars and theorists, simply it is the act of transferring written or oral items from a language or set of symbols into another one or another set of symbols. (Brockhaus, 1957) Venuti (1997) defines translation as the replacement of chain of source language's signifiers with the ones in target language. Additionally, Derrida (1976) presents language as an endless chain in which the signifiers are bound together and states that translation is differential and differed entity that never submits the genuine form because of the meaning is derived from the relations, similarities and differences of the signifiers. Newmark (1988) states that the process of translation is an act of transferring the sense in a text into other languages within the way of source language author's intention. Besides these definitions, there have been some explanations about the relationship between translation and culture. Translation is such a differential phenomenon that it has been influenced by the customs, traditions and changes in languages. As Lewis (2006) states that the variety of cultures is so huge and splendid. According to O'Neil, (2006) it is hard to submit the great number of various cultures that are scattered over the world.

The reflection of this multi-cultural existence can be seen in literature in which specific and social affairs, customs, traditions, religious thoughts and so on are declared by the authors of cultures. Language and culture are bound together in such a way that divides a nation from another in terms of its life style, unity of spirit in owning the same senses, feelings and thoughts. Each society has a national identity since it owns distinctive and unique structure within itself which makes it different among the others. Culture has a certain role of mirroring the social characteristics and features of a nation and these culture-based materials are firstly created in the original culture by the authors to the literal world and transformed into another language or form by the help of a set of symbols, language. For this reason, there exists a concrete connection between culture and literature since a great number of cultural items can be weaved into the literal world by the authors during the process of creating of art works.

In this study, a well-known novella, 72. Koğuş by Orhan Kemal and its two different translations made into English will be analysed descriptively in terms of the translation strategies that the translators utilized during the process of translating culture specific items. This novella tells the story of prisoners living in harsh conditions in jail within poverty, misery, hunger and corruption of human soul but the victory of human dignity against this corruption. Since the novella also narrates the life in prison, its culture and a unique jargon in jail that the prisoners develop, the reader of target language may not be informed about these culture specific items, it makes the translation of this masterpiece into another language much more difficult; by the way, it is high significance to examine the translations strategies in their transference into target culture and its reader. 
The reason to choose this novella is its being an art of work which includes culture specific items mostly and the fact that Orhan Kemal is a well-known author over the world whose works have been translated into a lot of languages and plays have been performed in many countries. The novella was turned into a play and screenplay afterwards and has been translated into a lot of languages as well. The novella was translated into English by Nevzat Erkmen with the name of 'Ward 72' in 1993 and by Cengiz Lugal as 'The Prisoners' in 2003. In this study, it is aimed to examine the culture specific items in source text ' 72 . Koğuş' descriptively and to detect which strategies were applied by the translators in their translations 'Ward 72' and 'The Prisoners'.

\section{As a novella 72. Koğuş and Prison Culture}

One of the art works of Orhan Kemal who is a well-known and fundamental master in Turkish literature, 72. Koğuş narrates the worst situation in which human soul is defeated. Orhan Kemal who kept his belief and goodwill for the humankind almost in all his works makes his reader hear the voice of rebellion against all the cruelty, misery and poverty even while narrating the lives of degraded men in the shade of a prison. In the novella, Orhan Kemal narrates the hope for human dignity that cannot be defeated by misery, poverty and corruption of human soul in a prison where uneducated people are jailed. Since the prisoners are illiterate and uneducated and belong to the lower class of society, utterances of prisoners in the novella mainly consist of proverbs, idioms and phrases related with local culture. According to Friedrich Maurer and Hans Naumann (cited from Röchrich and Mieder, 1977), uneducated and illiterate people make use of proverbs and idioms mostly in order to get rid of labour of thinking, on the other hand educated people have ability to utter whatever they think with their words per se.

In his novella, Orhan Kemal makes his characters speak in local dialect and they, especially prisoners, reflect their social class. Because of the fact that their education level is low and they are isolated away from society, they make use of slang and sometimes utilize from idioms and proverbs in order to enrich the narration. (Uslu, 2013) The social environment where the prisoners live is limited in terms of space, they develop their own language and culture. Therefore, it makes translation of these culture specific items difficult for translators to detect and transfer into another culture to be readable and understandable for target reader. Moreover, some formations and settlements that target culture does not have are mentioned and figured in the novella. These settlements can be defined as legal and illegal administrations. While legal affairs and items related with them may not be considered as strange by the target reader, illegal ones may not exist in target language and culture and by this way target reader may not be informed about these terms within illegal administration such as agha, baseman, entrance tax that is taken from newcomers to the ward by agha and illegal facilities such as gambling with dice and pacing the floor. Since the living conditions and styles are different in and out the prison, the difference between them would be reflected when associated in terms of culture. (Ayal1, 2012)

In this study, the 29th editionof 72. Koğuş was handled as the source text whose translations into English were made by Nevzat Erkmen in 1993 under the name of 'Ward 72' with the support of Ministry Culture and by Cengiz Lugal in 2003 under the name of 'The 
Prisoners'. The first version of the novella was presented to the reader with eleven stories in 1953, however it was printed as a unique art work apart from other stories. Afterwards, it was performed as a play on various stages of different countries throughout the world and translated into a lot of languages. In 1987, the novella was also transferred into the screen by Erdoğan Tokatlı and again by Murat Saraçoğlu in March 2011.In order to identify the methods and strategies used while making translation into English, two target texts, Ward 72 as Target Text 1 (TT1) and The Prisoners as Target Text 2 (TT2) were handled.

\section{Method}

Each nation owns a unique culture which involves traditions, customs, clothes, folklore and belief differing itself from the others. Since the words and phrases are inseparable units of language, it is hard to transfer them into another language or culture. These phrases may be related with the culture of a language and have a specific effect for the source language users. For that reason, transference of these culture specific items into another language may be troublesome or may not create the same effect in target language. (Yıldırım, 2015)

The term of 'Culture specific item' has been used by many scholars in order to identify the words and phrases that are related with the culture since there exist a great number of different cultures. As Lewis (2006) states "cultural diversity is vast and formidable". By this way, it causes difficulties in confirming the number of cultures since items related with society are not different in order to promote them as separate groups (O' Neil, 2006). For that reason, there is not certain knowledge in dividing the cultures over the world.

There may be similar items in many cultures for the fact that different cultures contact to each other, however these cultural items may be utilized by the societies in different ways (Zare-Behtash and Firoozkoohi, 2010). The cultural items may be understood in his own perspective by target culture reader rather than the view of source culture and the original text's author and this situation will cause a pitfall in translation of cultural items. However, it may be easy to find similar equivalent when the languages and cultures are close to each other (Larson, 1998).

Because of the various diversity of cultures, many theorists and scholars have studied upon the categorization of culture specific items. Studies upon translation was launched to shape in three distinct subtopics of this empirical science as descriptive, theoretical and applied after 1980s with the presentation of Holmes' basic map of 'Translation Studies' (Toury, 1995). Nida (2001), on the other hand, supports the idea that target culture reader and audience should have the flavour and pleasure of the equivalence in his own language after the source culture is translated by the translator.

Many definitions have been made in order to detect the words and phrases that are special and unique for the culture and rename these items in the terminology of that newly-developed discipline. Nord (1997) assigns the term as 'cultereme', Baker (1992) coins the term as 'culture specific concepts', Gambier (2007) develops these items as 'culture-specific references' and Robinson (1997) settles the terms of 'relia' and 'culture-bound phenomena'. In his book, 'A Textbook of Translation', Newmark (2004) refers to these materials as 'cultural words'. Lastly, 
Davies (2003) uses the term 'culture-specific items' in his dissertation and it is approved and has been used mostly by many scholars studying in the field of translation. In addition to these concepts, some functional theorists have claimed that translated text and target culture items bear higher significance than the source text and its culture (Tekalp, 2016).

In this study, the taxonomy that is discussed by Newmark (2004) will be used in order to detect culture-specific items in source and target texts. Newmark distinguishes culture-specific items in 5 categories:

1)Ecology

2)Material Culture (artefacts)

a) Food

b) Clothes

c) Housing

d) Transportation

3)Social Culture

a) Work

b) Leisure

4)Organisations, Customs, Activities, Procedures and Concepts

a) Political and Administrative

b) Religious

c) Artistic

5)Gestures and Habits

In order to minimize the problems and difficulties faced during the process of translation, Newmark (2004) proposes some procedures that translators can utilize to transfer CSIs into the target language. From a long list that constitutes of 16 translation procedures, 9 translation strategies were selected to determine the decisions that are applied by the translators. These translation strategies are listed as follows:

1) Literal Translation: The cultural items are translated by this strategy when they are clear and lucid. That is mostly used and one of the fundamental ways of translation applied in semantic and communicative texts.

2) Transference: Another basic method of translation is transference by which culture specific items in SL are transferred into target language as they are. When CSIs that do not exist in target language or culture such as geographical and historical places, names and nicknames of people, names of institution, journals and newspapers, etc., are detected in source text, they can be movedinto target text. This translation strategy can be named as 'loan words' by which the translator preserves source culture in target languages. 
3) Adaptation: Newmark defines this strategy as the replacement of CSIs in source culture with similar ones in target culture. However, the usage of this translation strategy may disappear CSIs' uniqueness.

4) Neutralization (Descriptive / Functional Equivalent): This way of translation are applied to cultural items by making them culture-free words in target language. When the culture-specific items cannot be transferred into the target language, they are neutralised and universalised in order to be understood by target reader.

5) Cultural Equivalent: when the culture specific items are not involved by target culture, it is replaced presumably by a target cultural word.

6) Explanation: It is a way of adding extra word for the culture specific items since it is understood by the target reader.

7) Deletion: Culture specific items can be removed by the translators from the target text occasionally. However, it is not recommended if there is no need for omission.

8) Paraphrase: This type of translation strategy is applied to culture specific items by expanding or rewriting the target text in order to be comprehended by target reader.

9) Naturalization: This strategy resembles to 'transference'.However, by this strategy, culture specific items are adapted to target language morphology.

\section{Analysis of Culture Specific Items}

In this study, some samples that selected randomly from the novella, 72. Koğuş, will be analysed with its two translations, 'Ward 72' and 'The Prisoners' in terms of Newmark's translation procedures that are given above in order to determine which strategies are benefitted by the translators in transferring the culture-specific items across the languages and cultures. In this part of the study, the CSIs will be analysed within the framework of Newmark's categorisation of cultural words.

\section{1) Ecology}

According to Newmark, this category includes culture specific items related with seasons, faunas, plains, hills, mountains and all the geographical features that are owned by a society. Many nations and countries possess 'local' words that gives information about their geographical features that are original and valued by themselves. For this reason, these terms that give specific information for source language users should be handled as culture specific items in the process of translation.

Sample 1.1:

\begin{tabular}{|c|c|}
\hline \multirow{3}{*}{ 72. Koğuş } & $\begin{array}{c}\text { Source Text } \\
\text { Orhan KEMAL }\end{array}$ \\
\cline { 2 - 3 } & "Dişarıda kuvvetli şubat fırtınası aysız, yıldızsız karanlıkları soğuk soğuk \\
döverken,..." (p.32)
\end{tabular}




\begin{tabular}{|c|c|c|c|c|}
\hline & “...the fierce February gale coldly ripped into the moonless, starless night.”(p.37) \\
\hline \multirow{2}{*}{$\begin{array}{c}\text { The } \\
\text { Prisoners }\end{array}$} & \multicolumn{4}{|c|}{ Target Text 2} \\
Cengiz LUGAL \\
\cline { 2 - 5 }
\end{tabular}

As an ecological culture specific item, "şubat firtınası" in the source text is handled as a general term and is translated into TL as "February gale" in TT1 and TT2 by utilizing from the methods of literal translation.

Sample 1.2:

\begin{tabular}{|c|c|c|c|c|}
\hline \multirow{2}{*}{ 72. Koğuş } & & & $\begin{array}{l}\text { e Text } \\
\text { KEMA }\end{array}$ & \\
\hline & \multicolumn{4}{|c|}{ "Sulusepken, ayaz, vicık vicık yerler." (p.66) } \\
\hline \multirow{3}{*}{ Ward 72} & \multicolumn{4}{|c|}{ Target Text 1} \\
\hline & \multicolumn{4}{|c|}{ Nevzat ERKMEN } \\
\hline & \multicolumn{4}{|c|}{ "Sleet, frost, and sticky, dirty mud everywhere..."(p.79) } \\
\hline \multirow{3}{*}{$\begin{array}{c}\text { The } \\
\text { Prisoners }\end{array}$} & \multicolumn{4}{|c|}{ Target Text 2} \\
\hline & \multicolumn{4}{|c|}{ Cengiz LUGAL } \\
\hline & \multicolumn{4}{|c|}{ "They were windswept, wet, and cold." (p.87) } \\
\hline $\begin{array}{c}\text { Newmark's } \\
\text { Method }\end{array}$ & TT1 & Literal Translation & TT2 & Neutralization \\
\hline
\end{tabular}

In this sample, "sulusepken" is a type of snowing with rain in some climates. While it is translated via literal translation as "sleet" in TT1, however, it is handled in TT2 as "windswept" by using the method of neutralization for the purpose of avoiding from an ambiguity for the target reader. As to the term, "ayaz" having the meaning of a heavy dry and frosty cold in a cool weather, it is transferred to the target language by utilizing the method of literal translation in TT1. However, it is transferred into the target language by using functional equivalent to make the target reader understand the term easily.

\section{Sample 1.3:}




\begin{tabular}{|c|c|c|c|c|}
\hline \multirow{2}{*}{ 72. Koğuş } & \multicolumn{4}{|c|}{$\begin{array}{c}\text { Source Text } \\
\text { Orhan KEMAL }\end{array}$} \\
\hline & \multicolumn{4}{|c|}{$\begin{array}{c}\text { "Kim bilir hangi insafsız karakışta parçalanıp koğuş betonunda yakılan çerçeveler } \\
\text { yeniden onarıldı,." (p.71) }\end{array}$} \\
\hline \multirow{3}{*}{ Ward 72} & \multicolumn{4}{|c|}{ Target Text 1} \\
\hline & \multicolumn{4}{|c|}{ Nevzat ERKMEN } \\
\hline & \multicolumn{4}{|c|}{$\begin{array}{l}\text { "The window frames, torn down in who knows which cruel, severewinter and } \\
\text { burnt on the ward concrete, were once again repaired and glazed."(p.86) }\end{array}$} \\
\hline \multirow{3}{*}{$\begin{array}{l}\text { The } \\
\text { Prisoners }\end{array}$} & \multicolumn{4}{|c|}{ Target Text 2} \\
\hline & \multicolumn{4}{|c|}{ Cengiz LUGAL } \\
\hline & \multicolumn{4}{|c|}{$\begin{array}{c}\text { "Once broken in a desperate bid for warmth, to build a little fire on the concrete } \\
\text { during somefreezing-cold winter many years ago," (p.94) }\end{array}$} \\
\hline $\begin{array}{l}\text { Newmark's } \\
\text { Method }\end{array}$ & TT1 & Paraphrase & TT2 & Paraphrase \\
\hline
\end{tabular}

In that sample, the ecological term "karakış", a compound name that refers to the harsh and coldest time of winter, is paraphrased into the target language for easy-understanding of the target reader in both target texts as it is a cultural term and hard to find an appropriate equivalence in the target culture. By this way, we can derive that these two translators benefited from paraphrase to submit the meaning of culture specific item in a way of rewriting and expanding the culture specific item with other words.

\section{2) Material Culture}

Newmark (1988) claims that words related with houses, cities, towns, households, transportations, foods, drinks and clothes may be involved in original and unique culture of the society. He distinguishes this category in four subtopics

\section{A. Foods}

Culture specific items that are related with foods and drinks will be analysed with their translations in target texts.

Sample 2.1.1:

\begin{tabular}{|c|c|}
\hline \multirow{2}{*}{ 72. Koğuş } & $\begin{array}{c}\text { Source Text } \\
\text { Orhan KEMAL }\end{array}$ \\
\cline { 2 - 3 } & "Ben olsam kurufasulye pişirtirdim!" (p.9) \\
\hline Ward 72 & Target Text 1 \\
\hline
\end{tabular}




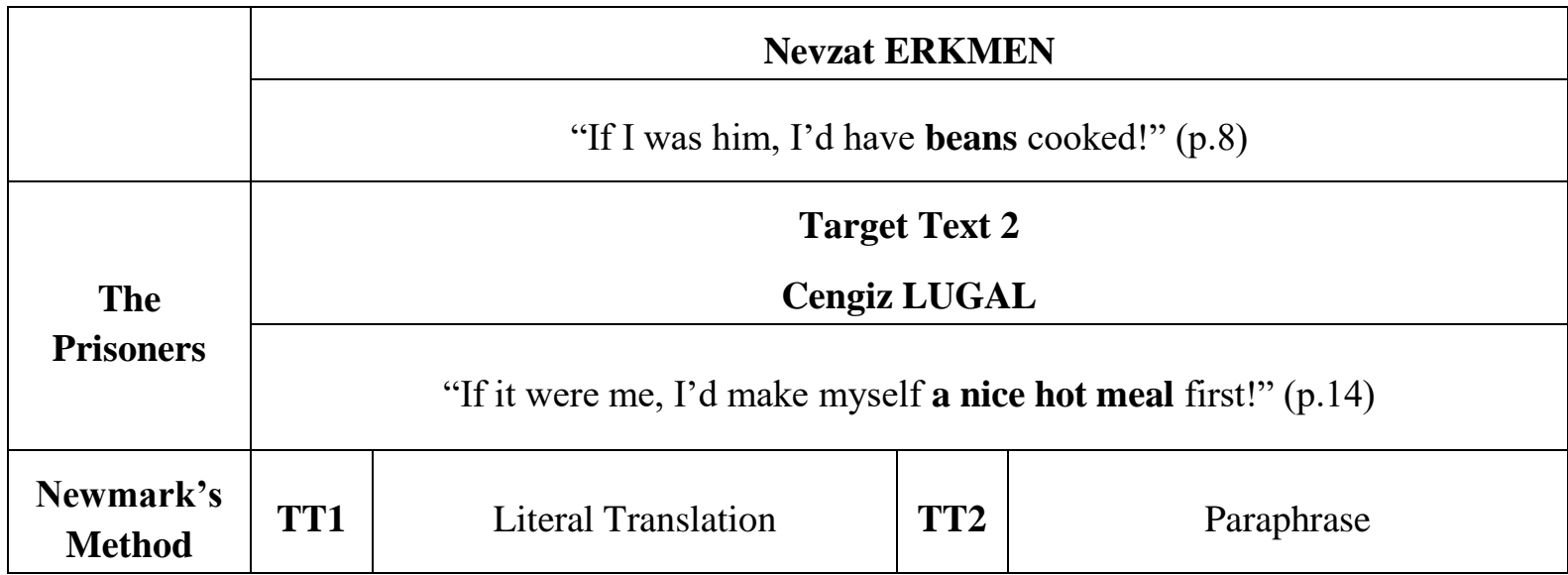

In some regions in the east, especially in Anatolia, the meal "kuru fasulye" is a common food that is made in Turkish cuisine within the mixture of white beans, onions, tomato sauce and sometimes with meat in itself and in world literature, it is mostly called as "white beans'. So, it stands for a popular and cultural food in Anatolia within the scope of Turkish cuisine. While this cultural food is translated in TT1 by utilizing from literal translation method in order to submit the culture specific material in the source text, it is transferred into the target language by paraphrasing the item in order to be understood by the target reader.

Sample 2.1.2:

\begin{tabular}{|c|c|c|c|c|}
\hline \multirow{2}{*}{ 72. Koğuş } & \multicolumn{4}{|c|}{$\begin{array}{c}\text { Source Text } \\
\text { Orhan KEMAL }\end{array}$} \\
\hline & \multicolumn{4}{|c|}{ "Pilav, yanında pilav da olursa..." (p.9) } \\
\hline \multirow{3}{*}{ Ward 72} & \multicolumn{4}{|c|}{ Target Text 1} \\
\hline & \multicolumn{4}{|c|}{ Nevzat ERKMEN } \\
\hline & \multicolumn{4}{|c|}{ "Pilau, if there is pilau with it." (p.8) } \\
\hline \multirow{3}{*}{$\begin{array}{c}\text { The } \\
\text { Prisoners }\end{array}$} & \multicolumn{4}{|c|}{ Target Text 2} \\
\hline & \multicolumn{4}{|c|}{ Cengiz LUGAL } \\
\hline & \multicolumn{4}{|c|}{ "With a nice pilaf to go with it..." (p.14) } \\
\hline $\begin{array}{c}\text { Newmark's } \\
\text { Method }\end{array}$ & TT1 & Naturalization & TT2 & Naturalization \\
\hline
\end{tabular}

Even if there has been no certain information about the origin of meal, "pilav", it is a traditional food and consumed generally in Anatolia and countries of Middle East. However, it 
is known all over the world because of its fame and anyone can see "pilav" in every culture. For this reason, it is known and consumed in English culture as well and this term is used in this language since it is a loan word that is taken from Arabic. Both of the translators transfer the item into the target language via naturalization by anglicising and adding some affixes to the word in order to adopt the word into English morphology and reduce the foreignness of the source text for the target readers. By this way, they prefer to domesticate the culture specific item via naturalization method by changing the last letter of the word to anglicise it.

Sample 2.1.3:

\begin{tabular}{|c|c|c|c|c|}
\hline \multirow{2}{*}{ 72. Koğuş } & \multicolumn{4}{|c|}{$\begin{array}{c}\text { Source Text } \\
\text { Orhan KEMAL }\end{array}$} \\
\hline & \multicolumn{4}{|c|}{ "Devlet baba her hükümlü gibi onlara da günde kara birer tayın veriyordu.”(p.16) } \\
\hline \multirow{3}{*}{ Ward 72} & \multirow{2}{*}{\multicolumn{4}{|c|}{$\begin{array}{c}\text { Target Text } 1 \\
\text { Nevzat ERKMEN }\end{array}$}} \\
\hline & & & & \\
\hline & \multicolumn{4}{|c|}{$\begin{array}{l}\text { "The government gave them each a daily ration apiece. Aloafofblackbread } \\
\text { sometimes ..."(p.17) }\end{array}$} \\
\hline \multirow{3}{*}{$\begin{array}{l}\text { The } \\
\text { Prisoners }\end{array}$} & \multicolumn{4}{|c|}{ Target Text 2} \\
\hline & \multicolumn{4}{|c|}{ Cengiz LUGAL } \\
\hline & \multicolumn{4}{|c|}{$\begin{array}{l}\text { "The state-issued standard rations of onedarkloaf each per day was all they had." } \\
\text { (p.24) }\end{array}$} \\
\hline $\begin{array}{c}\text { Newmark's } \\
\text { Method }\end{array}$ & TT1 & Neutralization & TT2 & Neutralization \\
\hline
\end{tabular}

In Turkish military culture, "taym" is a name given to the bread that is prepared for soldiers. It is smaller than common loaf of bread and its cooking style and fermentation is different from baking common bread. In order to be a square bread for soldiers, it is supported with whole-wheat flour or productive flour and it is fermented with grape juice (TDK, 2011). For this reason, it is not similar with loaf bread in terms of its cooking and fermentation. This culture specific bread is translated as "A loaf of black bread" in TT1 and "one dark loaf" in TT2. Both translators utilizes from descriptive equivalent to find an equivalence in target language. To constitute an image in target readers' mind, it is described as 'black loaf' in both translations.

\section{B. Clothes}

Terms related with clothes may be cultural since the traditions, national features and geographical changes such as climate can be effective in their being distinctive. For this reason, 
some culture specific items related with a society's clothes may not be translated easily. In this part, translators' decisions will be analysed in terms of Newmark's translation strategies.

Sample 2.2.1:

\begin{tabular}{|c|c|c|c|c|}
\hline \multirow{2}{*}{ 72. Koğuş } & \multicolumn{4}{|c|}{$\begin{array}{c}\text { Source Text } \\
\text { Orhan KEMAL }\end{array}$} \\
\hline & \multicolumn{4}{|c|}{ “...kirli kasketini çıkard1,...”(p.9) } \\
\hline \multirow{2}{*}{ Ward 72} & \multicolumn{4}{|c|}{ Target Text 1} \\
\hline & \multicolumn{4}{|c|}{ “...took off his dirty cap,..."(p.8) } \\
\hline \multirow{2}{*}{$\begin{array}{c}\text { The } \\
\text { Prisoners }\end{array}$} & \multicolumn{4}{|c|}{ Target Text 2} \\
\hline & \multicolumn{4}{|c|}{ “...took off his dirty cap,...”(p.14) } \\
\hline $\begin{array}{c}\text { Newmark's } \\
\text { Method }\end{array}$ & TT1 & Neutralization & TT2 & Neutralization \\
\hline
\end{tabular}

The word "kasket" comes from French into Turkish, and its origin is 'casquette' meaning small helmet for soldiers. However, this term is used in Turkish for hat covering the head with a shelter towards the face and worn by men, especially by villagers, in Turkey and Middle East (TDK, 2011). Since it is used in certain regions, it can be accepted as a culture specific items. In both translations, the translators used exactly the same method, functional equivalent, and translated as "cap" that is perceived as a typical soft hat by the target reader. In this sample, it can be stated that both two translations are made to domesticate this culture specific cloth for easy-understanding of target reader.

Sample 2.2.2:

\begin{tabular}{|c|c|}
\hline \multirow{3}{*}{ 72. Ko ğuş } & $\begin{array}{c}\text { Source Text } \\
\text { Orhan KEMAL }\end{array}$ \\
\cline { 2 - 3 } & "Bir gece, soğuk bir gece takasının içinde gocuğuna sikı sıkıya sarınarak oturmuş \\
sigara içerken...”(p.14)
\end{tabular}




\begin{tabular}{|c|c|c|c|}
\hline \multirow{2}{*}{$\begin{array}{c}\text { The } \\
\text { Prisoners }\end{array}$} & \multicolumn{4}{|c|}{$\begin{array}{c}\text { Target Text } 2 \\
\text { Cengiz LUGAL }\end{array}$} \\
\cline { 2 - 5 } & \multicolumn{2}{|c|}{ “..one evening while he was wrapped up in his raincoat, sitting in his boat and } \\
having a cigarette,...”(p.21)
\end{tabular}

In this sample, the item "gocuk"is a kind of one-piece coat made from a fur of an animal. While transferring this term into target language, the translator translates this term as "sheepskin cloak" andbenefits from literal translation by making the reader introduced with that culture specific item of source text in TT1. However, in TT2, it is transferred as "raincoat" into target language via adaptation by finding a similar object instead of the culture specific item.

Sample 2.2.3:

\begin{tabular}{|c|c|c|c|c|}
\hline \multirow[b]{2}{*}{ 72. Koğuş } & \multicolumn{4}{|c|}{$\begin{array}{c}\text { Source Text } \\
\text { Orhan KEMAL }\end{array}$} \\
\hline & \multicolumn{4}{|c|}{$\begin{array}{c}\text { “Ama bu sefer yalnız ekmek, yalnız rakı parası değil, allı, morlu, sanlı entarilerini } \\
\text { de düşüneceği bir Ayşe, bir Fatma bir Sultan, ya da adı ne olursa olsun, güzel bir } \\
\text { sevgilinin çaresine bakacaktı”(p.18) }\end{array}$} \\
\hline \multirow{3}{*}{ Ward 72} & \multirow{2}{*}{\multicolumn{4}{|c|}{$\begin{array}{c}\text { Target Text } 1 \\
\text { Nevzat ERKMEN }\end{array}$}} \\
\hline & & & & \\
\hline & \multicolumn{4}{|c|}{$\begin{array}{c}\text { "However, this time he would settle down with a young love named Ayşe, Fatma, } \\
\text { Sultan or whatever name she would also have to consider along with the bread and } \\
\text { the rak1 money."(p.20) }\end{array}$} \\
\hline \multirow{3}{*}{$\begin{array}{c}\text { The } \\
\text { Prisoners }\end{array}$} & \multicolumn{4}{|c|}{ Target Text 2} \\
\hline & \multicolumn{4}{|c|}{ Cengiz LUGAL } \\
\hline & \multicolumn{4}{|c|}{$\begin{array}{l}\text { "But this time he wanted more than just his daily bread and a drink. He wanted a } \\
\text { woman. Someone whose red, purple or yellow dresses he would have to } \\
\text { provide."(p.26) }\end{array}$} \\
\hline $\begin{array}{c}\text { Newmark's } \\
\text { Method }\end{array}$ & TT1 & Deletion & TT2 & Neutralization \\
\hline
\end{tabular}

Not known about its origin, "entari" comes from Arabic with its pronunciation as "anteri". This term is used for long one-piece garment that is generally worn at nights inside the home by both men and women in past. This type of cloth is still being worn by Arabic men in 
Middle East. (Kubbealt1, 2018) This term is deleted and not taken out in TT1 with the aim of keeping target reader away from unknown materials by its translator while it is adapted as "dress", a world-wide known material,into the target culture by the translator of TT2 for easyunderstanding of this culture specific garment within the strategy of functional equivalent.

\section{Housing}

Newmark (2004) proposes translators to handle some words that are related with a society's specific accommodations as culture specific items. In this part of the study, CSIs about living conditions and accommodations in source text will be analysed with their translations within the framework of Newmark's translation procedures.

Sample 2.3.1:

\begin{tabular}{|c|c|c|c|c|}
\hline \multirow{2}{*}{ 72. Koğuş } & \multicolumn{4}{|c|}{$\begin{array}{c}\text { Source Text } \\
\text { Orhan KEMAL }\end{array}$} \\
\hline & \multicolumn{4}{|c|}{ "Parayı alırken söyle başgardiyana, seni efendikoğuşuna versin." (p.12) } \\
\hline \multirow{3}{*}{ Ward 72} & \multicolumn{4}{|c|}{ Target Text 1} \\
\hline & \multicolumn{4}{|c|}{ Nevzat ERKMEN } \\
\hline & \multicolumn{4}{|c|}{$\begin{array}{c}\text { "When you get the money from the Head Warden, ask him to put you } \\
\text { intheeffendiward."(p.14) }\end{array}$} \\
\hline \multirow{3}{*}{$\begin{array}{l}\text { The } \\
\text { Prisoners }\end{array}$} & \multicolumn{4}{|c|}{ Target Text 2} \\
\hline & \multicolumn{4}{|c|}{ Cengiz LUGAL } \\
\hline & \multicolumn{4}{|c|}{$\begin{array}{l}\text { "When you go to get your money, tell the Governor to transfer you to one of } \\
\text { theGentlemen'sDormitories."(p.19) }\end{array}$} \\
\hline $\begin{array}{c}\text { Newmark's } \\
\text { Method }\end{array}$ & TT1 & Transference & TT2 & Literal Translation \\
\hline
\end{tabular}

In prison culture, 'efendi koğuşu' bears the meaning of a cell or prison only rich and elite persons in Turkey and Middle East. This culture specific items is translated in TT1 as 'effendi ward' by utilizing from transference and as 'gentlemen's dormitory' in TT2 within the framework of literal translation.

Sample 2.3.2:

\begin{tabular}{|c|c|}
\hline \multirow{3}{*}{ 72. Koğuş } & $\begin{array}{c}\text { Source Text } \\
\text { Orhan KEMAL }\end{array}$ \\
\cline { 2 - 3 } & "Ona topaç gibi oğlanlar doğurup yemeğini pişirecek, çeşmeden suyunu \\
& taşıacak," (p.19)
\end{tabular}




\begin{tabular}{|c|c|c|c|c|}
\hline \multirow{2}{*}{ Ward 72} & \multicolumn{4}{|c|}{$\begin{array}{c}\text { Target Text } 1 \\
\text { Nevzat ERKMEN }\end{array}$} \\
\hline & \multicolumn{4}{|c|}{$\begin{array}{c}\text { "This wife would bear him sturdy sons, cook his meals, carry his water from the } \\
\text { fountain,..." (p.20) }\end{array}$} \\
\hline \multirow{3}{*}{$\begin{array}{l}\text { The } \\
\text { Prisoners }\end{array}$} & \multicolumn{4}{|c|}{ Target Text 2} \\
\hline & \multicolumn{4}{|c|}{ Cengiz LUGAL } \\
\hline & \multicolumn{4}{|c|}{$\begin{array}{l}\text { "Someone to bear him healthy sons, to cook for him, to carry water from } \\
\text { thewell,..." (p.26) }\end{array}$} \\
\hline $\begin{array}{c}\text { Newmark's } \\
\text { Method }\end{array}$ & TT1 & Literal Translation & TT2 & Cultural Equivalent \\
\hline
\end{tabular}

In Ottoman Empire, water holds a unique and spiritual place. It is referred with God's mercy and grace, for this reason, it is given utmost importance to spread the water near the people to civilize the humanity and life, itself. Fountains were being made at every corner of the streets and quarters where people lived in Turkish culture and generally named with noble persons (Büyükkol, 2017). This culture specific item is translated in TT1 as 'fountain' via literal translation and as 'well' within the scope of cultural equivalent by finding a culturally appropriate item since 'well' is mostly used and culturally bound material to supply the need of water.

Sample 2.3.3:

\begin{tabular}{|c|c|c|c|c|}
\hline \multirow{2}{*}{ 72. Koğuş } & \multicolumn{4}{|c|}{$\begin{array}{c}\text { Source Text } \\
\text { Orhan KEMAL }\end{array}$} \\
\hline & \multicolumn{4}{|c|}{$\begin{array}{c}\text { "Geceyi İstanbul'da, Sirkeci ya da Tepebaşı'ndaki bir otelde geçirip ertesi gün } \\
\text { sabah sabah atllyorlar kocaman bir vapura." (p.88) }\end{array}$} \\
\hline \multirow{3}{*}{ Ward 72} & \multicolumn{4}{|c|}{ Target Text 1} \\
\hline & \multicolumn{4}{|c|}{ Nevzat ERKMEN } \\
\hline & \multicolumn{4}{|c|}{$\begin{array}{l}\text { "Spending the night at a hotel in İstanbul, at Sirkeci or Tepebaşı, they hop onto a } \\
\text { big ship." (p.105) }\end{array}$} \\
\hline \multirow{3}{*}{$\begin{array}{l}\text { The } \\
\text { Prisoners }\end{array}$} & \\
\hline & \multicolumn{4}{|c|}{ Cengiz LUGAL } \\
\hline & \multicolumn{4}{|c|}{$\begin{array}{l}\text { "They'd spend the night in a hotel in town. The next day they would get up, and } \\
\text { get on a large passenger ship." (p.114) }\end{array}$} \\
\hline $\begin{array}{c}\text { Newmark's } \\
\text { Method }\end{array}$ & TT1 & Transference & TT2 & Neutralization \\
\hline
\end{tabular}


'Sirkeci' and 'Tepebaşı' are two main quarters of Istanbul. For these proper names belong to place names, they are involved in the categorisation of houses, towns and countries. These culture specific items are translated in TT1 via transference by introducing source culture to target reader while in TT2, they are given with a general term, town, within the framework of neutralization (descriptive equivalent) to be understood by target reader supposing they may not be known in target culture.

\section{Transportation}

Newmark (2004) claims that nations may own various models of transportation and signs, symbols may be variable between cultures. For example, there may exist a lot of word in order to define a vehicle. For this reason, every culture specific item related with traffic and transportation in the source and target texts will be categorised and analysed in this part of the study.

Sample 2.4.1:

\begin{tabular}{|c|c|c|c|c|}
\hline \multirow{2}{*}{ 72. Koğuş } & \multicolumn{4}{|c|}{$\begin{array}{c}\text { Source Text } \\
\text { Orhan KEMAL }\end{array}$} \\
\hline & \multicolumn{4}{|c|}{$\begin{array}{l}\text { "Bir gece, soğuk bir gece takasının içinde gocuğuna sıkı sıkıya sarınarak oturmuş } \\
\text { sigara içerken kahvecinin çırağı küçük Haşan gelmiş, haberi vermişti."(p.14) }\end{array}$} \\
\hline \multirow{3}{*}{ Ward 72} & \multicolumn{4}{|c|}{ Target Text 1} \\
\hline & \multicolumn{4}{|c|}{ Nevzat ERKMEN } \\
\hline & \multicolumn{4}{|c|}{$\begin{array}{l}\text { "One night one cold night, while he was sitting in his taka, tightly wrapped in } \\
\text { hissheepskin cloak and smoking a cigarette,Hasan, the little boy in the coffeehouse, } \\
\text { had come and told him."(p.15-16) }\end{array}$} \\
\hline \multirow{3}{*}{$\begin{array}{c}\text { The } \\
\text { Prisoners }\end{array}$} & \multicolumn{4}{|c|}{ Target Text 2} \\
\hline & \multicolumn{4}{|c|}{ Cengiz LUGAL } \\
\hline & \multicolumn{4}{|c|}{$\begin{array}{l}\text { "The errand-boy from his regular café, Hasan, had come over to him one evening } \\
\text { while he was wrapped up in his raincoat, sitting in his boat and having a cigarette, } \\
\text { and given him the news."(p.21) }\end{array}$} \\
\hline $\begin{array}{c}\text { Newmark's } \\
\text { Method }\end{array}$ & TT1 & Transference & TT2 & Neutralization \\
\hline
\end{tabular}

In this sample, 'taka' in source text bears the meaning of coasting vessel with a sail which is peculiar to East Blacksea region in Turkey, therefore, it may be evaluated among culture specific items. This CSI is translated in TT1 with the same word via transference. However, it is handled with functional equivalent since it is supposed by the translator that 'taka' may not clear and visible to understand for target reader. 
Sample 2.4.2:

\begin{tabular}{|c|c|c|c|c|}
\hline \multirow{2}{*}{ 72. Koğuş } & \multicolumn{4}{|c|}{$\begin{array}{c}\text { Source Text } \\
\text { Orhan KEMAL }\end{array}$} \\
\hline & \multicolumn{4}{|c|}{ “Dedüler var bir şilep, çıkacak sefere, gider misun?”(p.39) } \\
\hline \multirow{3}{*}{ Ward 72} & \multicolumn{4}{|c|}{ Target Text 1} \\
\hline & \multicolumn{4}{|c|}{ Nevzat ERKMEN } \\
\hline & \multicolumn{4}{|c|}{ "They said, 'There's a steamer, ready to put to sea, you want to go?"(p.46) } \\
\hline \multirow{3}{*}{$\begin{array}{c}\text { The } \\
\text { Prisoners }\end{array}$} & \multicolumn{4}{|c|}{ Target Text 2} \\
\hline & \multicolumn{4}{|c|}{ Cengiz LUGAL } \\
\hline & \multicolumn{4}{|c|}{ "They said 'There's acargoboat due to leave, do you want to take it?"(p.52) } \\
\hline $\begin{array}{l}\text { Newmark's } \\
\text { Method }\end{array}$ & TT1 & Adaptation & TT2 & Literal Translation \\
\hline
\end{tabular}

In this sample, 'şilep' can be described as a boat carrying heavy load in the oceans. In TT1, this term is seen as a cultural word and it is transferred into target language via adaptation by finding a similar equivalent. However, it translated in TT2 literally and transferred as 'cargo boat'.

Sample 2.4.3:

\begin{tabular}{|c|c|}
\hline \multirow{3}{*}{ 72. Koğuş } & $\begin{array}{c}\text { Source Text } \\
\text { Orhan KEMAL }\end{array}$ \\
\cline { 2 - 3 } & "Köprü, kirli kurşuni deniz, 1slak mavnalar..."(p.66) \\
\hline \multirow{3}{*}{ Ward 72 } & $\begin{array}{c}\text { Target Text 1 } \\
\text { Nevzat ERKMEN }\end{array}$ \\
\cline { 2 - 2 } & "The bridge, dirty lead colored sea, wet barges..."(p.79) \\
\hline \multirow{2}{*}{ The } & $\begin{array}{c}\text { Target Text 2 } \\
\text { Cengiz LUGAL }\end{array}$ \\
\cline { 2 - 2 } & "Over the bridge looking out to the dirty grey sea, and past the damp, dripping \\
& greengrocers'..."(p.87) \\
\hline
\end{tabular}




\begin{tabular}{|c|c|c|c|c|}
\hline $\begin{array}{c}\text { Newmark's } \\
\text { Method }\end{array}$ & TT1 & Literal Translated & TT2 & Mistranslated \\
\hline
\end{tabular}

'Mavna' is a cultural word given to undecked ships that port burden to close coasts and liners, is translated via literal translation in TT1. On the other hand, it is mistranslated by the translator of TT2 by taking the source text into account as 'manav', not 'mavna',

\section{3) Social Culture}

One of the main problems in translation is to recognize the difference between denotative and connotative meaning of the words that are used in order to define the cultural items related with social materials. Newmark (2004) distinguishes the cultural words about social culture as to their usage at work or leisure times to minimize the complexity caused by connotative words.

\section{A. Work}

Sample 3.1.1:

\begin{tabular}{|c|c|c|c|c|}
\hline \multirow{2}{*}{ 72. Koğuş } & \multicolumn{4}{|c|}{$\begin{array}{c}\text { Source Text } \\
\text { Orhan KEMAL }\end{array}$} \\
\hline & \multicolumn{4}{|c|}{ “Ăgam değil mi?”(p.11) } \\
\hline \multirow{3}{*}{ Ward 72} & \multicolumn{4}{|c|}{ Target Text 1} \\
\hline & \multicolumn{4}{|c|}{ Nevzat ERKMEN } \\
\hline & \multicolumn{4}{|c|}{ "Isn't he myAgha?"(p.12) } \\
\hline \multirow{3}{*}{$\begin{array}{c}\text { The } \\
\text { Prisoners }\end{array}$} & \multicolumn{4}{|c|}{ Target Text 2} \\
\hline & \multicolumn{4}{|c|}{ Cengiz LUGAL } \\
\hline & \multicolumn{4}{|c|}{ "Listen, I'm looking out for theboss."(p.17) } \\
\hline $\begin{array}{c}\text { Newmark's } \\
\text { Method }\end{array}$ & TT1 & Naturalization & TT2 & Adaptation \\
\hline
\end{tabular}

'Agha', having various meanings in Turkish culture, bears here the meaning of a person who dominates one or more parts of the prison illegally and reigns over other prisoners thanks to the power and wealth in Turkish prison culture. This term is transferred into target culture in TT1 via naturalization by making arrangements upon the word in order to adapt it to target language morphology. However, in TT2, this culture specific item is translated within the scope of adaptation by finding a similar equivalent in target language. The second method may have caused the CSI to lose its uniqueness and originality in target text. 
Sample 3.1.2

\begin{tabular}{|c|c|c|c|c|}
\hline \multirow{2}{*}{ 72. Koğuş } & \multicolumn{4}{|c|}{$\begin{array}{c}\text { Source Text } \\
\text { Orhan KEMAL }\end{array}$} \\
\hline & \multicolumn{4}{|c|}{ "Bulaşıklarını yıkarım, çamaşırını yıkarım, sırtını keselerim hamamda.”(p.12) } \\
\hline \multirow{3}{*}{ Ward 72} & \multicolumn{4}{|c|}{ Target Text 1} \\
\hline & \multicolumn{4}{|c|}{ Nevzat ERKMEN } \\
\hline & \multicolumn{4}{|c|}{$\begin{array}{c}\text { "I wash your dishes, I wash your clothes, I rub your back with a glove } \\
\text { inthehammam."(p.14) }\end{array}$} \\
\hline \multirow{3}{*}{$\begin{array}{l}\text { The } \\
\text { Prisoners }\end{array}$} & \multicolumn{4}{|c|}{ Target Text 2} \\
\hline & \multicolumn{4}{|c|}{ Cengiz LUGAL } \\
\hline & \multicolumn{4}{|c|}{$\begin{array}{l}\text { "I'll do your dishes, I'll do your clothes, and I'll scrub your back } \\
\text { inthebaths."(p.19) }\end{array}$} \\
\hline $\begin{array}{l}\text { Newmark's } \\
\text { Method }\end{array}$ & TT1 & Naturalization & TT2 & Literal Translation \\
\hline
\end{tabular}

In Turkish culture, 'hamam' means an architecture where the people take bath. It may be found at home or somewhere else open to public as a business. This cultural word is translated in TT1 as 'hammam' via the method naturalization within the scope of target language morphology while it is translated as 'bath' by the way of literal translation in TT2.

Sample 3.1.3:

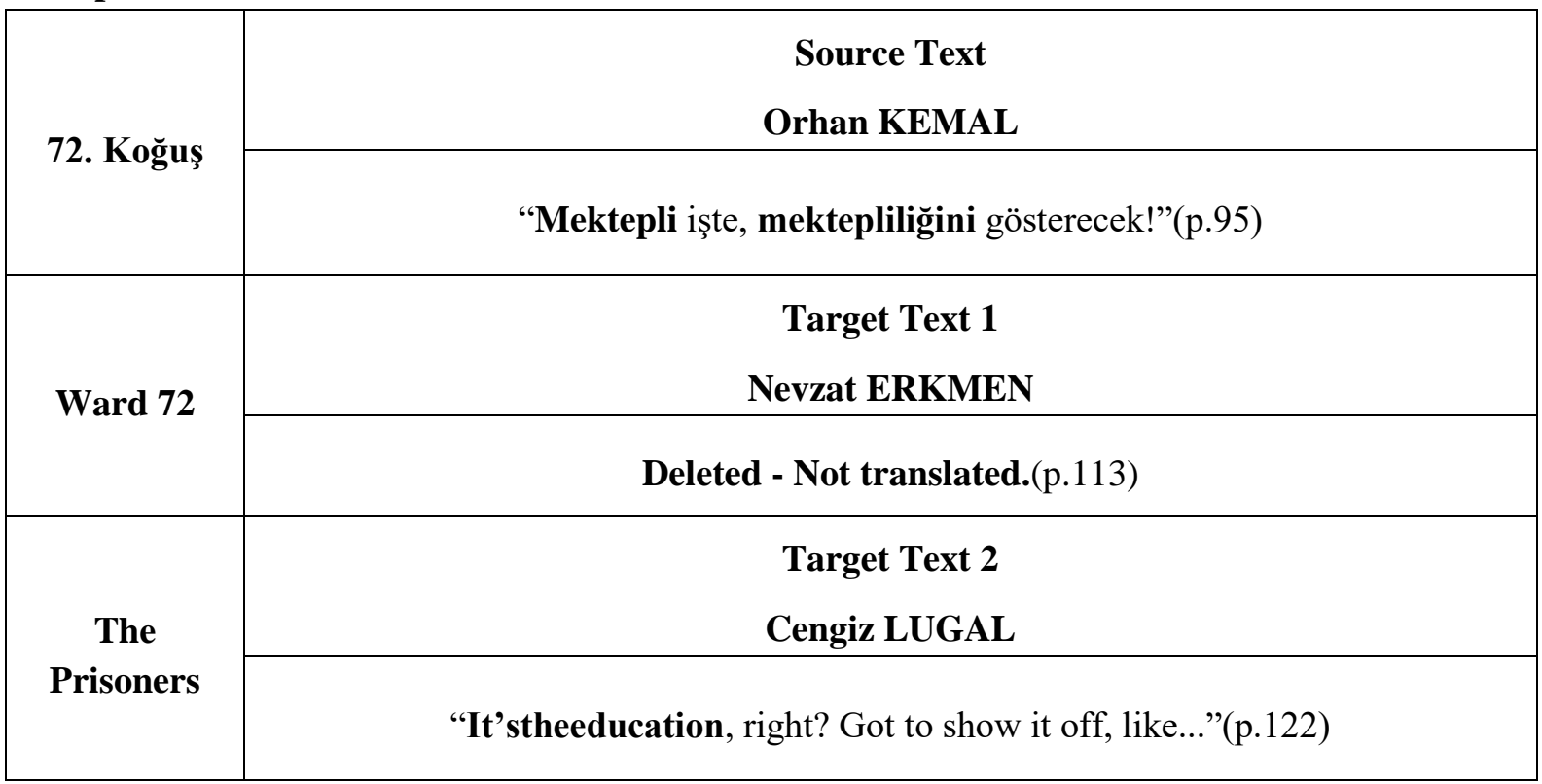




\begin{tabular}{|c|c|c|c|c|}
\hline $\begin{array}{c}\text { Newmark's } \\
\text { Method }\end{array}$ & TT1 & Deletion & TT2 & Paraphrase \\
\hline
\end{tabular}

In this sample, the term 'mektepli' has connotative meaning that implies a person who is well-educated. This cultural item is paraphrased in TT2 in order to give similar sense to target reader while it is omitted in TT1 by the use of deletion method since it may be seen as an unnecessary cultural detail by the translator. However, deletion of the culture specific item completely is not suggested by many scholars and theorists because of the loss of meaning.

\section{B. Leisure}

Sample 3.2.1:

\begin{tabular}{|c|c|c|c|c|}
\hline \multirow{2}{*}{ 72. Koğuş } & \multicolumn{4}{|c|}{$\begin{array}{c}\text { Source Text } \\
\text { Orhan KEMAL }\end{array}$} \\
\hline & \multicolumn{4}{|c|}{$\begin{array}{l}\text { “Kumarcıların arkasındaki duvarın önüne boylu boyunca serilmiş, dirsekkeyfi } \\
\text { yapan kısa, kalın adamın yumuk gözleri açıldı ilkin, şüpheyle baktı.”(p.2) }\end{array}$} \\
\hline \multirow{3}{*}{ Ward 72} & \multicolumn{4}{|c|}{ Target Text 1} \\
\hline & \multicolumn{4}{|c|}{ Nevzat ERKMEN } \\
\hline & \multicolumn{4}{|c|}{$\begin{array}{c}\text { "The short, stocky man was stretched out full length by the wall behind the dicers, } \\
\text { with hisheadrestingonhiselbow."(p.2) }\end{array}$} \\
\hline \multirow{3}{*}{$\begin{array}{l}\text { The } \\
\text { Prisoners }\end{array}$} & \multicolumn{4}{|c|}{ Target Text 2} \\
\hline & \multicolumn{4}{|c|}{ Cengiz LUGAL } \\
\hline & \multicolumn{4}{|c|}{$\begin{array}{l}\text { "A short, stocky man wasrestingonhiselbows in front of the wall behind the dice } \\
\text { players."(p.8) }\end{array}$} \\
\hline $\begin{array}{l}\text { Newmark's } \\
\text { Method }\end{array}$ & TT1 & Paraphrase & TT2 & Paraphrase \\
\hline
\end{tabular}

As an act of leisure time activity, 'dirsek keyfi' stands for a cultural word having the meaning of resting one's head on his elbow. This culture specific item is translated by the two translators via paraphrase method by utilizing from some other extra words to define this movement to target language reader.

Sample 3.2.2:

\begin{tabular}{|c|c|}
\hline \multirow{2}{*}{ 72. Koğuş } & $\begin{array}{c}\text { Source Text } \\
\text { Orhan KEMAL }\end{array}$ \\
\cline { 2 - 3 } & "Her gece dertleşiriz onunla biz."(p.10) \\
\hline
\end{tabular}




\begin{tabular}{|c|c|c|c|}
\hline \multirow{3}{*}{ Ward 72 } & \multicolumn{2}{|c|}{$\begin{array}{c}\text { Target Text 1 } \\
\text { Nevzat ERKMEN }\end{array}$} \\
\cline { 2 - 4 } & \multicolumn{2}{|c|}{ "Every night we talkabouteachother'sproblemsandthings, he and I."(p.10-11) } \\
\cline { 2 - 4 } $\begin{array}{c}\text { The } \\
\text { Prisoners }\end{array}$ & \multicolumn{3}{|c|}{$\begin{array}{c}\text { Target Text 2 } \\
\text { Cengiz LUGAL }\end{array}$} \\
\cline { 2 - 4 } $\begin{array}{c}\text { Newmark's } \\
\text { Method }\end{array}$ & TT1 & \multicolumn{3}{|c|}{ "I keep him company every evening,..."(p.16) } \\
\hline
\end{tabular}

The cultural verb 'dertleşmek'is given by the source text writer in the novella as an idiom and stands for the act of some persons' pour their grief to each other in order to get rid of the sorrow they suffer and get relaxed by talking about problems. This culture specific item is translated in TT1 by giving explanation while it is paraphrased in TT2 with the term of 'keeping company'.

Sample 3.2.3:

\begin{tabular}{|c|c|c|c|c|}
\hline \multirow{2}{*}{ 72. Koğuş } & \multicolumn{4}{|c|}{$\begin{array}{c}\text { Source Text } \\
\text { Orhan KEMAL }\end{array}$} \\
\hline & \multicolumn{4}{|c|}{ “...Akşamları da çaykaynatırız.”(p.12) } \\
\hline \multirow{3}{*}{ Ward 72} & \multicolumn{4}{|c|}{ Target Text 1} \\
\hline & \multicolumn{4}{|c|}{ Nevzat ERKMEN } \\
\hline & \multicolumn{4}{|c|}{ “... in the evenings webrewtea.”(p.13) } \\
\hline \multirow{3}{*}{$\begin{array}{c}\text { The } \\
\text { Prisoners }\end{array}$} & \multicolumn{4}{|c|}{ Target Text 2} \\
\hline & \multicolumn{4}{|c|}{ Cengiz LUGAL } \\
\hline & \multicolumn{4}{|c|}{ “... and we'llbrewupanicecuppa in the evening.”(p.19) } \\
\hline $\begin{array}{c}\text { Newmark's } \\
\text { Method }\end{array}$ & TT1 & Literal Translation & TT2 & Cultural Equivalent \\
\hline
\end{tabular}

The culture specific item 'çay kaynatmak' may not exist in every culture in which tea is not a common drink and known. However, in many cultures, various types of tea may be consumed and for that reason, the target reader might be informed before. This term is 
translated in TT1 by means of literal translation while it is changed with cuppa, a common cultural equivalent from target culture. In TT2, it is detected that the translator utilizes from cultural equivalent since he replaces a CSI with another common one in target culture.

\section{4) Organisations, Customs, Activities, Procedures and Concepts}

Newmark (2004) proposes to categorize the cultural words related with social facilities, concepts, customs and traditions under this topic. In that category, geographical names, institutions, habitats and workplaces can be analysed in three subtopics as politicaladministrative, religious and artistic.

\section{A. Political-Administrative}

Sample 4.1.1:

\begin{tabular}{|c|c|c|c|c|}
\hline \multirow{2}{*}{ 72. Koğuş } & \multicolumn{4}{|c|}{$\begin{array}{c}\text { Source Text } \\
\text { Orhan KEMAL }\end{array}$} \\
\hline & \multicolumn{4}{|c|}{ "Yahu idareden çağırıyorlar dedik, başefendi çağırıyor dedik be!"(p.5) } \\
\hline \multirow{2}{*}{ Ward 72} & \multicolumn{4}{|c|}{$\begin{array}{c}\text { Target Text } 1 \\
\text { Nevzat ERKMEN }\end{array}$} \\
\hline & \multicolumn{4}{|c|}{$\begin{array}{l}\text { "Hey, I told you they're callin' you from the office. I said the Head Warden's } \\
\text { callin' you, man!'(p.6) }\end{array}$} \\
\hline \multirow{2}{*}{$\begin{array}{l}\text { The } \\
\text { Prisoners }\end{array}$} & \multicolumn{4}{|c|}{ Target Text 2} \\
\hline & \multicolumn{4}{|c|}{ "Man, I told you they wanted you at the office. TheGov'nor's waiting!"(p.12) } \\
\hline $\begin{array}{c}\text { Newmark's } \\
\text { Method }\end{array}$ & TT1 & Literal Translation & TT2 & Adaptation \\
\hline
\end{tabular}

As a title that is for seniors in government offices or army among the soldiers, 'başefendi' is categorised in administrative category and this term is translated 'head warden' in TT1 by the use of literal translation while it is applied to target text as ' the gov'nor' via adaptation by finding a similar equivalent item in target language.

Sample 4.1.2:

\begin{tabular}{|c|c|}
\hline \multirow{2}{*}{ 72. Koğuş } & Source Text \\
& Orhan KEMAL \\
\hline
\end{tabular}




\begin{tabular}{|c|c|c|c|c|}
\hline & \multicolumn{4}{|c|}{ “Muhtar oğluyum.” (p.24) } \\
\hline \multirow{3}{*}{ Ward 72} & \multicolumn{4}{|c|}{ Target Text 1} \\
\hline & \multicolumn{4}{|c|}{ Nevzat ERKMEN } \\
\hline & \multicolumn{4}{|c|}{ "I'm the son of a villageelder."'(p.27) } \\
\hline \multirow{3}{*}{$\begin{array}{c}\text { The } \\
\text { Prisoners }\end{array}$} & \multicolumn{4}{|c|}{ Target Text 2} \\
\hline & \multicolumn{4}{|c|}{ Cengiz LUGAL } \\
\hline & \multicolumn{4}{|c|}{ "I'm the son of a villageelder." (p.33) } \\
\hline $\begin{array}{c}\text { Newmark's } \\
\text { Method }\end{array}$ & TT1 & Adaptation & TT2 & Adaptation \\
\hline
\end{tabular}

Selected via election in order to run administrative facilities in a village or quarter, 'muhtar' stands for a cultural item related with both political and administrative concept in Turkish culture (TDK, 2011). Even though this term is also used by other countries, this political status may not exist in some of the western cultures. This CSI is transferred into target culture via adaptation method in both target texts by finding a similar status, 'village elder', that is a wise person whose thoughts are respected by others in terms of religion and politics of a group or society.

\section{Sample 4.1.3:}

\begin{tabular}{|c|c|c|}
\hline \multirow{4}{*}{ 72. Koğuş } & $\begin{array}{c}\text { Source Text } \\
\text { Orhan KEMAL }\end{array}$ \\
\cline { 2 - 3 } & "Kaya Ali'nin başköşeye sermekte olduğu yatağın yanına geldiler." (p.24) \\
\hline \multirow{3}{*}{ Ward 72 } & $\begin{array}{c}\text { Target Text } 1 \\
\text { Nevzat ERKMEN }\end{array}$ \\
\cline { 2 - 3 } & "They both went to the side of the mattress Kaya Ali was putting in the place of \\
& honor."(p.27) \\
\hline \multirow{3}{*}{ Prisone } & $\begin{array}{c}\text { Target Text } 2 \\
\text { Cengiz LUGAL }\end{array}$ \\
\cline { 2 - 3 } & "They went over to the mattress that Rock Ali had now spread out in the corner." \\
& & (p.33) \\
\hline
\end{tabular}




\begin{tabular}{|c|c|c|c|c|}
\hline $\begin{array}{c}\text { Newmark's } \\
\text { Method }\end{array}$ & TT1 & Paraphrase & TT2 & Neutralization \\
\hline
\end{tabular}

As a culture specific item, 'başköşe' signifies a place where is reserved for a respectful person or elders to sit. This culture specific item is paraphrased in TT1 as 'the place of honor' while it is neutralized by the translator of TT2 with a simple descriptive equivalent, 'corner', in target language.

\section{B. Religious}

Sample 4.2.1:

\begin{tabular}{|c|c|c|c|c|}
\hline \multirow{2}{*}{ 72. Koğuş } & \multicolumn{4}{|c|}{$\begin{array}{c}\text { Source Text } \\
\text { Orhan KEMAL }\end{array}$} \\
\hline & \multicolumn{4}{|c|}{ "Hafız oğluyum ben,.." (p.1) } \\
\hline \multirow{3}{*}{ Ward 72} & \multicolumn{4}{|c|}{ Target Text 1} \\
\hline & \multicolumn{4}{|c|}{ Nevzat ERKMEN } \\
\hline & \multicolumn{4}{|c|}{ "I'm the son of a Hafiz."(p.1) } \\
\hline \multirow{3}{*}{$\begin{array}{c}\text { The } \\
\text { Prisoners }\end{array}$} & \multicolumn{4}{|c|}{ Target Text 2} \\
\hline & \multicolumn{4}{|c|}{ Cengiz LUGAL } \\
\hline & \multicolumn{4}{|c|}{ Not Translated - Deleted } \\
\hline $\begin{array}{c}\text { Newmark's } \\
\text { Method }\end{array}$ & TT1 & Transference & TT2 & Deletion \\
\hline
\end{tabular}

As a religious item, 'hafiz' means a person who knows the secret book of Muslims, Quran, in Islamic culture. That cultural word is translated via transference method while it is deleted by the translator of TT2 as it is seen as unknown and confusing culture specific material for target reader.

Sample 4.2.2:

\begin{tabular}{|c|c|}
\hline \multirow{2}{*}{ 72. Koğuş } & $\begin{array}{c}\text { Source Text } \\
\text { Orhan KEMAL }\end{array}$ \\
\cline { 2 - 3 } & "Aslını yitirene haramzade derler aslanım!” (p.20) \\
\hline Ward 72 & Target Text $\mathbf{1}$ \\
\hline
\end{tabular}




\begin{tabular}{|c|c|c|c|}
\hline \multirow{2}{*}{$\begin{array}{c}\text { The } \\
\text { Prisoners }\end{array}$} & \multicolumn{3}{|c|}{ Nevzat ERKMEN } \\
\cline { 2 - 4 } & "He who denies his origin is a bastard, chief!" (p.21) \\
\cline { 2 - 4 } & \multicolumn{3}{|c|}{$\begin{array}{c}\text { Target Text 2 } \\
\text { Cengiz LUGAL }\end{array}$} \\
\hline $\begin{array}{c}\text { Newmark's } \\
\text { Method }\end{array}$ & TT1 & Lou're not worth shit if you forget where your roots are!" (p. 27) \\
\hline
\end{tabular}

As a slang used in east culture, 'haramzade' stands for a person or a child that were born as result of a relationship without marriage. This slang is translated into target language within the scope of literal translation while it is transferred via adaptation by finding a similar utterance, 'to be not worth shit, bearing the meaning of a useless person in target culture.

Sample 4.2.3:

\begin{tabular}{|c|c|c|c|c|}
\hline \multirow{2}{*}{ 72. Koğuş } & \multicolumn{4}{|c|}{$\begin{array}{c}\text { Source Text } \\
\text { Orhan KEMAL }\end{array}$} \\
\hline & \multicolumn{4}{|c|}{$\begin{array}{l}\text { “ikindileri kadınlar kırmızı kiremitli yapılarının önündeki bu yeşillikte birbirlerine } \\
\text { sokularak ağır, uslu oturuyorlardı sözde." (p.73) }\end{array}$} \\
\hline \multirow{3}{*}{ Ward 72} & \multicolumn{4}{|c|}{ Target Text 1} \\
\hline & \multicolumn{4}{|c|}{ Nevzat ERKMEN } \\
\hline & \multicolumn{4}{|c|}{$\begin{array}{l}\text { "In the afternoons, sitting closely together on the greenery in front of their red } \\
\text { tiled building, the women pretended to sit quietly, behaving themselves." (p.87) }\end{array}$} \\
\hline \multirow{3}{*}{$\begin{array}{l}\text { The } \\
\text { Prisoners }\end{array}$} & \multicolumn{4}{|c|}{ Target Text 2} \\
\hline & \multicolumn{4}{|c|}{ Cengiz LUGAL } \\
\hline & \multicolumn{4}{|c|}{$\begin{array}{l}\text { "The women prisoners would come out in the afternoon and sit together on this } \\
\text { green carpet in front of their red-tiled building." (p. 96) }\end{array}$} \\
\hline $\begin{array}{l}\text { Newmark's } \\
\text { Method }\end{array}$ & TT1 & Literal Translation & TT2 & Literal Translation \\
\hline
\end{tabular}

The religious word, 'ikindi' implies the time between noon and evening in a day. However, it originates from prayer times in Islamic religion and attributed as the second half of the day 
(Kubbealt1, 2018). This culture specific item is translated as 'afternoon' via literal translations in both target texts.

C. Artistic

Sample 4.3.1:

\begin{tabular}{|c|c|c|c|c|}
\hline \multirow{2}{*}{ 72. Koğuş } & \multicolumn{4}{|c|}{$\begin{array}{c}\text { Source Text } \\
\text { Orhan KEMAL }\end{array}$} \\
\hline & \multicolumn{4}{|c|}{ “Granitten yontulmuş çok eski birHititheykeline bezniyordu"(p.3) } \\
\hline \multirow{2}{*}{ Ward 72} & \multicolumn{4}{|c|}{ Target Text 1} \\
\hline & \multicolumn{4}{|c|}{ "He had the appearance of a very old Hittitestatue carved from granite."(p.2) } \\
\hline \multirow{2}{*}{$\begin{array}{c}\text { The } \\
\text { Prisoners }\end{array}$} & \multicolumn{4}{|c|}{ Cengiz LUGAL } \\
\hline & \multicolumn{4}{|c|}{ "He had the appearance of an ancient Hittitestatue, hewn of solid rock." (p.8) } \\
\hline $\begin{array}{l}\text { Newmark's } \\
\text { Method }\end{array}$ & TT1 & Literal Translation & TT2 & Literal Translation \\
\hline
\end{tabular}

In this sample, a monument special to Hittite civilization is figured out in source text in order to imply stability and inactiveness of a person. This cultural metaphor is translated in both target texts as 'Hittite statue' via literal translation.

Sample 4.3.2:

\begin{tabular}{|c|c|}
\hline \multirow{4}{*}{ 72. Koğuş } & $\begin{array}{c}\text { Source Text } \\
\text { Orhan KEMAL }\end{array}$ \\
\cline { 2 - 3 } & "Uzun favorili Rum oğlu bulmuş kafayı, alafrangabirtürküyle meyhaneyi kiliseye \\
çevirmektedir." (p.66)
\end{tabular}




\begin{tabular}{|c|c|c|c|c|}
\hline & \multicolumn{4}{|c|}{ "He'd got drunk, and come out with a foreignsong that made the place seem like a } \\
church." (p. 87)
\end{tabular}

As a folkloric item, 'türkü' generally gives information about a nation's cultural structure, by this way it should be treated as a culture specific item of a society. The CSI, 'alafranga türkü', is translated in TT1 via literal translation. However, it is paraphrased in TT2 with the term of 'foreign song'.

Sample 4.3.3:

\begin{tabular}{|c|c|c|c|c|}
\hline \multirow{2}{*}{ 72. Koğuş } & \multicolumn{4}{|c|}{$\begin{array}{c}\text { Source Text } \\
\text { Orhan KEMAL }\end{array}$} \\
\hline & \multicolumn{4}{|c|}{ “Kalın sesli biri uzaktan uzağa "MapushaneÇeşmesi”"ni söylüyordu." (p.80) } \\
\hline \multirow{3}{*}{ Ward 72} & \multicolumn{4}{|c|}{ Target Text 1} \\
\hline & \multicolumn{4}{|c|}{ Nevzat ERKMEN } \\
\hline & \multicolumn{4}{|c|}{ “Far-off, someone’s hoarse-voice was singing, “PrisonFountain”.”(p.97) } \\
\hline \multirow{3}{*}{$\begin{array}{c}\text { The } \\
\text { Prisoners }\end{array}$} & \multicolumn{4}{|c|}{ Target Text 2} \\
\hline & \multicolumn{4}{|c|}{ Cengiz LUGAL } \\
\hline & \multicolumn{4}{|c|}{ "Someone with a deep voice was singing sadly in the distance." (p. 106) } \\
\hline $\begin{array}{c}\text { Newmark's } \\
\text { Method }\end{array}$ & TT1 & Literal Translation & TT2 & Deletion \\
\hline
\end{tabular}

Besides being culture specific item, the term, 'mapushane çeşmesi', is known as the name of a song that is written upon the theme of love in prison in source culture. While this CSI is translated in TT1 within the scope of literal translation, it is deleted by the translator in TT2.

\section{5) Gestures and Habits}

\section{Sample 5.1:}

\section{Koğuş}

Source Text 


\begin{tabular}{|c|c|c|c|c|}
\hline & \multicolumn{4}{|c|}{ Orhan KEMAL } \\
\hline & \multicolumn{4}{|c|}{ “Omuzsilkti.”(p.3) } \\
\hline \multirow{3}{*}{ Ward 72} & \multicolumn{4}{|c|}{ Target Text 1} \\
\hline & \multicolumn{4}{|c|}{ Nevzat ERKMEN } \\
\hline & \multicolumn{4}{|c|}{ “He shruggedhisshoulders.”(p.3) } \\
\hline \multirow{3}{*}{$\begin{array}{c}\text { The } \\
\text { Prisoners }\end{array}$} & \multicolumn{4}{|c|}{ Target Text 2} \\
\hline & \multicolumn{4}{|c|}{ Cengiz LUGAL } \\
\hline & \multicolumn{4}{|c|}{ "He shrugged,..." (p.9) } \\
\hline $\begin{array}{c}\text { Newmark's } \\
\text { Method }\end{array}$ & TT1 & Literal Translation & TT2 & Literal Translation \\
\hline
\end{tabular}

In this sample, 'omuz silkmek' implies the act of disregarding to someone or not caring something. This culture specific item is translated literally in both target texts.

Sample 5.2:

\begin{tabular}{|c|c|c|c|c|}
\hline \multirow{2}{*}{ 72. Koğuş } & \multicolumn{4}{|c|}{$\begin{array}{c}\text { Source Text } \\
\text { Orhan KEMAL }\end{array}$} \\
\hline & \multicolumn{4}{|c|}{ "Kaptan yatağına bağdaşkurmuştu,..." (p.35) } \\
\hline \multirow{3}{*}{ Ward 72} & \multicolumn{4}{|c|}{ Target Text 1} \\
\hline & \multicolumn{4}{|c|}{ Nevzat ERKMEN } \\
\hline & \multicolumn{4}{|c|}{ "The Captain had satcross-legged on his mattress." (p.41) } \\
\hline \multirow{3}{*}{$\begin{array}{c}\text { The } \\
\text { Prisoners }\end{array}$} & \multicolumn{4}{|c|}{ Target Text 2} \\
\hline & \multicolumn{4}{|c|}{ Cengiz LUGAL } \\
\hline & \multicolumn{4}{|c|}{ "Captain satcross-legged on his mattress." (p. 47) } \\
\hline $\begin{array}{c}\text { Newmark's } \\
\text { Method }\end{array}$ & TT1 & Adaptation & TT2 & Adaptation \\
\hline
\end{tabular}


As a traditional sitting style, the term 'bağdaş kurmak' is generally adopted in Anatolia and Middle East in order to sit in a relaxing way. This CSI is translated by the two translators by finding a similar way of sitting, but not the same in target texts. Therefore, we can state that this cultural word is transferred into target language by the use of adaptation method.

Sample 5.3:

\begin{tabular}{|c|c|c|c|c|}
\hline \multirow{2}{*}{ 72. Koğuş } & \multicolumn{4}{|c|}{$\begin{array}{c}\text { Source Text } \\
\text { Orhan KEMAL }\end{array}$} \\
\hline & \multicolumn{4}{|c|}{ “Tavukçu, Kaya Ali’yi dirsekledi.” (p.68) } \\
\hline \multirow{3}{*}{ Ward 72} & \multicolumn{4}{|c|}{ Target Text 1} \\
\hline & \multicolumn{4}{|c|}{ Nevzat ERKMEN } \\
\hline & \multicolumn{4}{|c|}{ “Chickener nudged Kaya Ali withhiselbow."(p.81) } \\
\hline \multirow{3}{*}{$\begin{array}{c}\text { The } \\
\text { Prisoners }\end{array}$} & \multicolumn{4}{|c|}{ Target Text 2} \\
\hline & \multicolumn{4}{|c|}{ Cengiz LUGAL } \\
\hline & \multicolumn{4}{|c|}{ “Chicken nudged Rock Ali.”(p.89) } \\
\hline $\begin{array}{c}\text { Newmark's } \\
\text { Method }\end{array}$ & TT1 & Explanation & TT2 & Literal Translation \\
\hline
\end{tabular}

As a gesture made generally between the conversations to warn a person, 'dirseklemek' in the source text is transferred into target language via explanation method by giving more detail to define the act in TT1. However, it is translated via literal translation by avoiding extra words in TT2.

\section{Conclusion}

In recent years, studies upon cultural components of literary works have gained importance. Besides the differences between the languages in terms of syntax and linguistic aspects, cultural diversity makes the process of translation hard for translators. Culture is shaped and constituted with the diachronic evolution of a community by means of language, translation from one language to another can be appreciated as a cross-cultural transference. Since the thoughts, beliefs, traditions, life styles and concepts are effective in creating a nation's culture, these cultural items are involved when the literary works are being shaped (Ünalan, 2004).

As a literary work, '72. Koğuş' owns a splendid place in world literature in reflecting fundamental cultural values of Turkish society. Even though it has been translated into many languages and performed on the stage a lot of times, there exist some shortcomings in submitting the whole of culture to target language and its reader. In this study, it is aimed to 
detect and analyse translators' decisions during the process of translation in terms of translation methods. 33 randomly selected culture specific items in the source text were detected in its two translations 'Ward 72' that was translated by Nevzat Erkmen in 1993 and 'The Prisoners' that was translated by Cengiz Lugal in 2003 and these CSIs were analysed within the framework of Newmark's translation procedures after they were categorised according to Newmark's cultural wordclassification.

After data was gathered, it is clearly seen that the mostly used method that the translators utilized is literal translation.However, this information should not be an implication for that the two translations of the source text tend to move in the same direction since there exist some evidences about the fact that the translators have utilized from various techniques different from themselves which leads them in reverse directions.

Considering the CSIs that are selected, it is clearly seen that literal translation method is used by TT1 translator with a higher percentage (\%42) than the other target text rate (\% 24). TT1 translator has heavily used this method in the translation of $4^{\text {th }}$ topic - organisations, customs, activities, procedures and concepts. It is detected in the study that the method from which the translator has never utilized is cultural equivalent. The methods that the translator has rarely applied to TT1 are neutralization, explanation and deletion with the rate of $\% 6$ in all. As it can be derived from this explanation, TT1 translator has aimed to introduce flavour of the source culture to target reader and wanted these CSIs to be known by target reader while transferring the cultural words across the languages. Hence, his decision that is spread throughout the text is supported with his explanation that is given for the description of characters' names at the beginning of novella.

As to the CSIs' analyses in TT2, it is seen that mostly used translation method is literal translation. However, the rate of literal translation (\%24) does not make any sense about the issue of introducing source culture elements to target reader when the rates of other translation methods that are used by the translator are considered. The translator has utilized from the methods; adaptation, paraphrase with the rate of $\% 18$ and neutralization at the rate of $\% 21$ with the aim of better comprehension for target reader in order to avoid from ambiguity. Therefore, the translator pursues the goal of submitting an easy-understanding for target reader to give him the impression just like reading in his own literature rather than introducing source culture components.

In conclusion, according to the data that is gathered and evaluations, it is seen that two different goals were pursued by two different translators of the same source text in translating its culture specific items into the same target language. On the one hand, one of the translators has decided to introduce the variety and richness of source culture to target reader, on the other hand the other one chose to apply a better understanding of source culture elements for target language users. By this way, it is aimed to enlighten translators' decisions and choices in transferring a culture into another language. In a further study, the opinions of translators may be asked in order to clarify the reasons in employing the translation methods and some subtopics such as proper names, idioms, slang and metaphors may be adopted into the classification of cultural words. 


\section{REFERENCES}

Ayal1, Ş. (2012). Hapishane Romanlarl (1950-1980). (Master Thesis), Balıkesir: Balıkesir University.

Baker, M. (1992). In Other Words: A Course Book on Translation. London: Routledge.

Büyükkol, S. (2017). Çeşme Kültürünün Türk Resmine Yansımaları.İdil Dergisi,6(39).

Davies, E. E. (2003). A Goblin or a Dirty Nose? The Treatment of Culture-Specific References in Translations of Harry Potter Book. The Translator, 9(1), 65-100.

Der Große Brockhaus. (1957), 16. Press, Germany:Wiesbaden.

Derrida, J. (1976).Of Grammatology, tr. G. C. Spivak, Baltimore, MD and London: Johns.

Gambier, Y. (2007).Doubts and Directions in TranslationStudies, The Netherlands: John Benjamins.

Holmes, J. S. (1972).The Nature of Translation: Essays on the Theory and Practice of Literary Translation, The Hague and Paris: Mouton.

Kemal, O. (2015). 72. Koğuş. 29th. Ed. İstanbul: Everest Yayınları.

Kemal, O. (1993).Ward 72. (Tr.Nevzat Erkmen).Ankara: Publications of Ministry of Culture. ISBN: 975-17-1235-1

Kemal, O. (2003). The Prisoners. (Tr. Cengiz Lugal). (Ed: Denise Mcqueen) İstanbul: Anatolia Publishing.

Kubbealt1 Lugat1, Accessed 07 June 2018,http://lugatim.com/.

Larson, M. L. (1998).Meaning-Based Translation: A Guide to Cross-Language Equivalence 2nd ed.Lanham and Maryland: University Press of America, Inc.

Lewis, R. D.(2006).When Cultures Collide: Leading across Cultures.Boston and London:Nicolas Brealey International.

Munday, J. (2008). Introducing Translation Studies (2nd Edition ed.). USA and Canada: Routledge.

Newmark, P. (1988).Textbook of Translation. Oxford: Pergamon Press.

Nord, C. (1997a). “Text Analysis in Translation.” In Annotated Texts for Translation: EnglishGerman. Functionalist Approaches Illustrated. Schäffner, Christina and Uwe Wiesemann. Frankfurt: Multilingual Matters, 24.

Nord, C.(1997b). Translating as a Purposeful Activity: Functionalist Approaches Explained. Manchester: St. Jerome.

Nida, E. (2001). Contexts in Translating. Amsterdam/Philadelphia: John Benjamins Publishing Company. 
O’Neil, D. 6 June 2006. World Diversity Patterns. Accessed on 7June 2018. http://anthro.palomar.edu/ethnicity/ethnic_5.htm

Robinson, D. (1997). Becoming A Translator: An Accelerated Course. London \& New York: Routledge.

Röhrich, L. \& Wolfgang M. (1977).Sprichwort. Stuttgart: Metzler

Tekalp, S.(2016).Translating Popular Fiction: A Descriptive Study on the Turkish Translation of The Hunger Games, International Journal of Language and Literature,4(2), DOI: 10.15640/ijll.v4n2a14

TDK Türkçe Sözlük.(2011).Prepared by: Şükrü Haluk Akalın. 11. Ed. Ankara: Türk Dil Kurumu.

Toury, G.(1995). Descriptive Translation Studies and Beyond. Philadephia: John Benjamins Publishing Co.

Uslu, A.(2013).Kerimcan Korcan'ın Hapishane Konulu Hikaye ve Romanlarında Hapishane Gerçeği, (Master Thesis), Eskişehir: Eskişehir Osmangazi University.

Ünalan, Ş. (2004). Dil ve Kültür. Ankara: Nobel Yayın Dağıtım.

Venti, L. (1997). The Translator's Invisibility: A History of Translation, Routledge, New York.

Yıldırım, C. (2015). Amin Maalouf'un Afrikalı Leo ve Semerkant Romanlarında Kültürel Unsurların Çevirisi Üzerine Bir İnceleme, The Journal of International Social Research,3(39).

Zare-Behtash, E. and Firoozkohi, S. (2010). Culture-Specific Items in Literary Translations. Accessed 08 June 2018. http://www.bokorlang.com/journal/51culture.htm 